\title{
OCCURRENCE OF NITRATE IN GROUND WATER IN THE WHITE RIVER BASIN, INDIANA, 1994-95
}

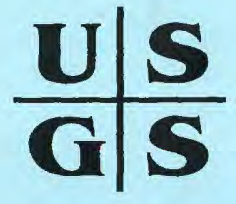

U.S. Department of the Interior-U.S. Geological Survey

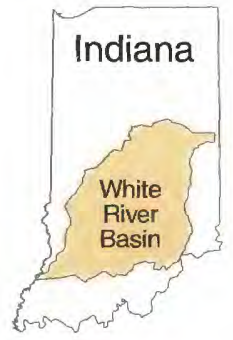

\begin{abstract}
Nitrogen-based fertilizers are used extensively in the White River Basin. Water samples were collected for nitrate analysis from 103 monitoring wells in four networks in the basin. Ninetyfour "shallow" wells were screened near the top of the uppermost aquifer encountered; the remaining 9 wells were paired with shallow wells but screened 18 to 45 feet deeper. Samples from 6.4 percent of the shallow wells exceeded the U.S. Environmental Protection Agency's Maximum Contaminant Level of $10 \mathrm{mg} / \mathrm{L}$ (milligrams per liter). Elevated nitrate concentrations (higher than $3 \mathrm{mg} / \mathrm{L}$ ) were common in unconfined, permeable deposits underlying agricultural areas; nitrate concentrations decreased with depth in these deposits. Low nitrate concentrations (less than $0.05 \mathrm{mg} / \mathrm{L}$ ) were found in aquifers confined by clay-rich tills that retard downward movement of nitrate and oxygen into the ground water.
\end{abstract}

\section{INTRODUCTION}

In 1991, the U.S. Geological Survey (USGS) began the National Water-Quality Assessment (NAWQA) Program. The long-term goals of the NAWQA Program are to describe the status and trends in the quality of the Nation's surface and ground water and to provide a sound scientific understanding of the primary natural and human factors affecting the quality of these resources (Hirsch and others, 1988).

The White River Basin in Indiana was among the first 20 river basins to be studied as part of the NAWQA program. A component of the White River Basin study is to determine the occurrence of nitrate in the shallow ground water of the basin. This fact sheet describes nitrate data collected from 103 monitoring wells from June 1994 through August 1995.

\section{DESCRIPTION OF THE WHITE RIVER BASIN}

The White River Basin is part of the Mississippi River system and encompasses 11,350 square miles of central and southern Indiana (fig. 1). The population of the White River Basin in 1990 was approximately 2.1 million; the Indianapolis Metropolitan Area accounted for about 60 percent of the total population.

Approximately 55 percent of the population in the White River Basin relies on ground water as the primary source of drinking water. In 1993, about 180 million gallons per day (Mgal/d) of ground water were withdrawn in the basin. By comparison, $270 \mathrm{Mgal} / \mathrm{d}$ of surface water were withdrawn, excluding withdrawals used for cooling water at thermoelectric power plants. Of the total ground-water withdrawals, public-water suppliers accounted for about 51 percent $(91 \mathrm{Mgal} / \mathrm{d})$, followed by selfsupplied domestic users ( 23 percent) and self-supplied industrial and commercial users (20 percent) (Scott Dinwiddie, Indiana Department of Natural Resources, Division of Water, written commun., 1995).

The principal land use in the basin is agriculture (fig. 2), which covers about 70 percent of the basin. In 1992, about 22 percent of the basin was planted in corn, and about 18 percent was planted in soybeans. Other cropland comprises a smaller percentage of the

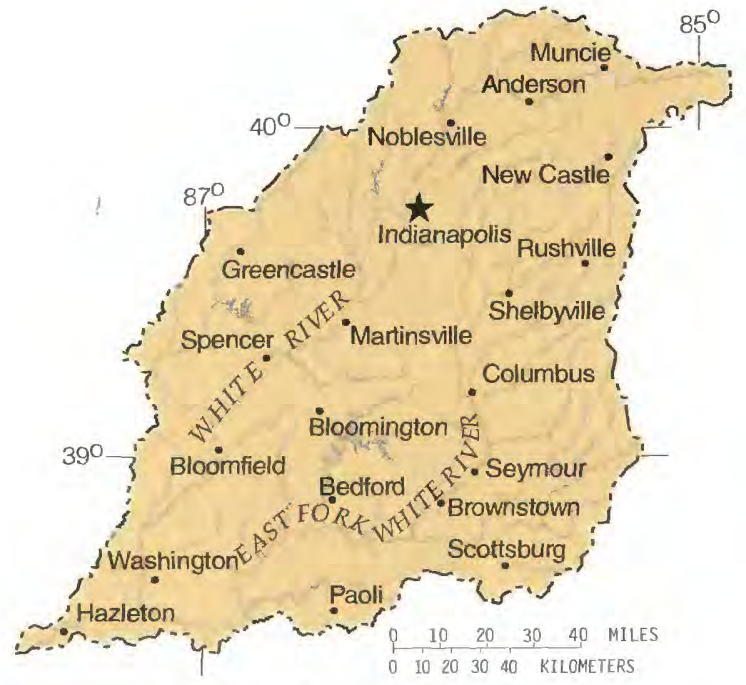

Figure 1. The White River Basin, Indiana.

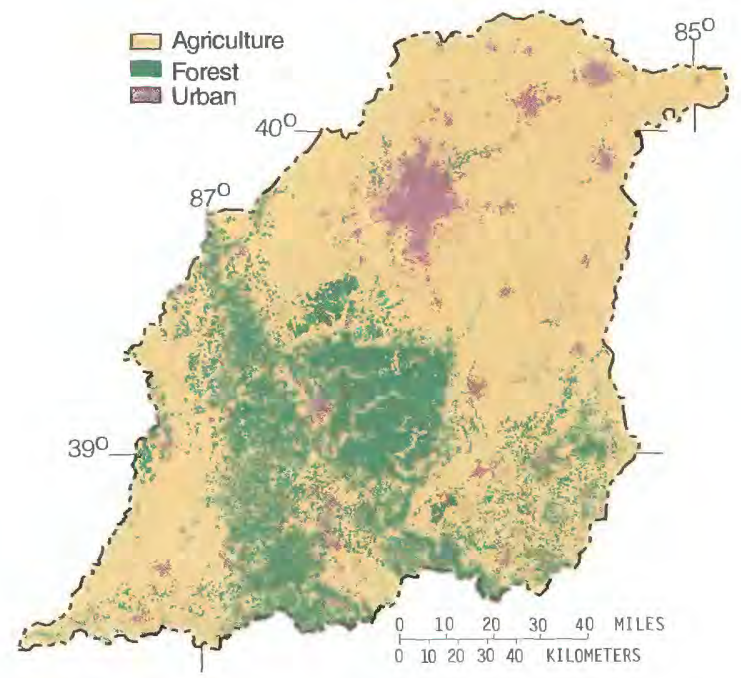

Figure 2. Land use in the White River Basin, Indiana. 
basin and includes wheat and hay. Most of the forested land is located in the south-central part of the basin. There is significant industrialization in the cities of Indianapolis, Muncie, and Anderson.

For the purposes of this study, the White River Basin was divided into six hydrogeomorphic regions (fig. 3). These regions are based on factors affecting water quality, such as geology, physiography, and hydrology. Three regions - the bedrock upland, bedrock lowland and plain, and karst plain - are defined primarily by bedrock characteristics. The remaining three regions - the till plain, glacial lowland, and fluvial deposits_-are defined primarily by characteristics of glacial deposits and are the focus of this fact sheet.

The till plain, which covers the northern part of the basin, typically is underlain by 100 to 200 feet of silty-clay till interlayered with thin (5- to 10-foot-thick) layers of sand and gravel. Waterbearing units in the upper 50 feet of the till sequence consist of confined sand and gravel lenses that commonly do not provide sufficient yields for domestic use. The glacial lowland in the southwestern part of the basin typically is covered by 0 to 100 feet of loess (wind-blown silt), silty-clay till, dune sands, and lake clays that overlie coal-bearing shales and sandstones. Shallow unconsolidated water-bearing units rarely provide sufficient yields for domestic use; most privately-owned wells are completed in bedrock. The fluvial (river) deposits fill river valleys that cut across the other five hydrogeomorphic regions. The fluvial deposits consist of approximately 10 to 100 feet of sand, gravel, and silt beneath and adjacent to most of the major streams in the basin. The fluvial deposits are most extensive along the White River near Indianapolis and south of Bloomfield and along the East Fork White River near Columbus and Seymour. The fluvial deposits are highly permeable and recharge rapidly, properties that make them productive aquifers, but vulnerable to contamination.

\section{FACTORS AFFECTING NITRATE IN GROUND WATER}

The primary source of nitrate in ground water in the White River Basin is nitrogen fertilizer. Commercial fertilizer applied to agricultural and urban land accounts for approximately two-thirds of the estimated total nitrogen input to the basin (Jeff Martin, U.S. Geological Survey, written commun., 1995). Other important nonpoint sources of nitrogen in the basin include manure, decomposing crop residues, septic systems, atmospheric deposition, and fixation of atmospheric nitrogen (Jeff Martin, written commun., 1995).

Nitrogen in the soil of the White River Basin commonly is in the form of nitrate. The primary mechanism for nitrate removal from the soil is plant uptake. However, nitrate can leach downward into ground water when nitrate concentrations in the soil exceed plant uptake. Where dissolved oxygen concentrations in ground water are low-less than $1 \mathrm{mg} / \mathrm{L}$ (milligram per liter)-this excess nitrate can be removed by denitrification (the biochemical conversion of nitrate to nitrogen gas by bacteria). The potential for nitrate contamination of ground water is generally dependent on the following factors: (1) amount of fertilizer and other nitrogen sources input to the soil; (2) amount of rainfall; (3) permeability of the surficial geologic

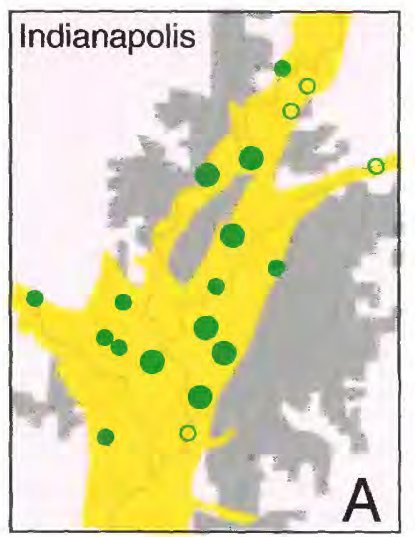

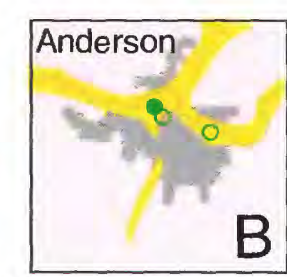

Urban areas on insets are shaded gray

EXPLANATION

HYDROGEOMORPHIC REGIONS

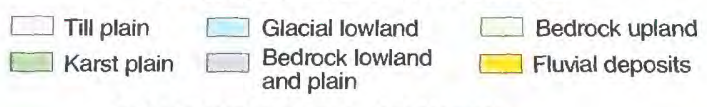

MONITORING-WELL NETWORK:

WELL ENVIRONMENTAL SETTING (hydrogeomorphic region/land use)

- 0 Till plain/agricultural

- Glacial lowland/agricultural

- - Fluvial deposits/agricultural

- 0 Fluvial deposits/urban (see insets A, B, and C)

L Symbol size and fill denote concentr ation of nitrate as nitrogen (in milligrams per liter)

less than 0.05

$0.05-3.0$

$3.1-10$

greater than 10
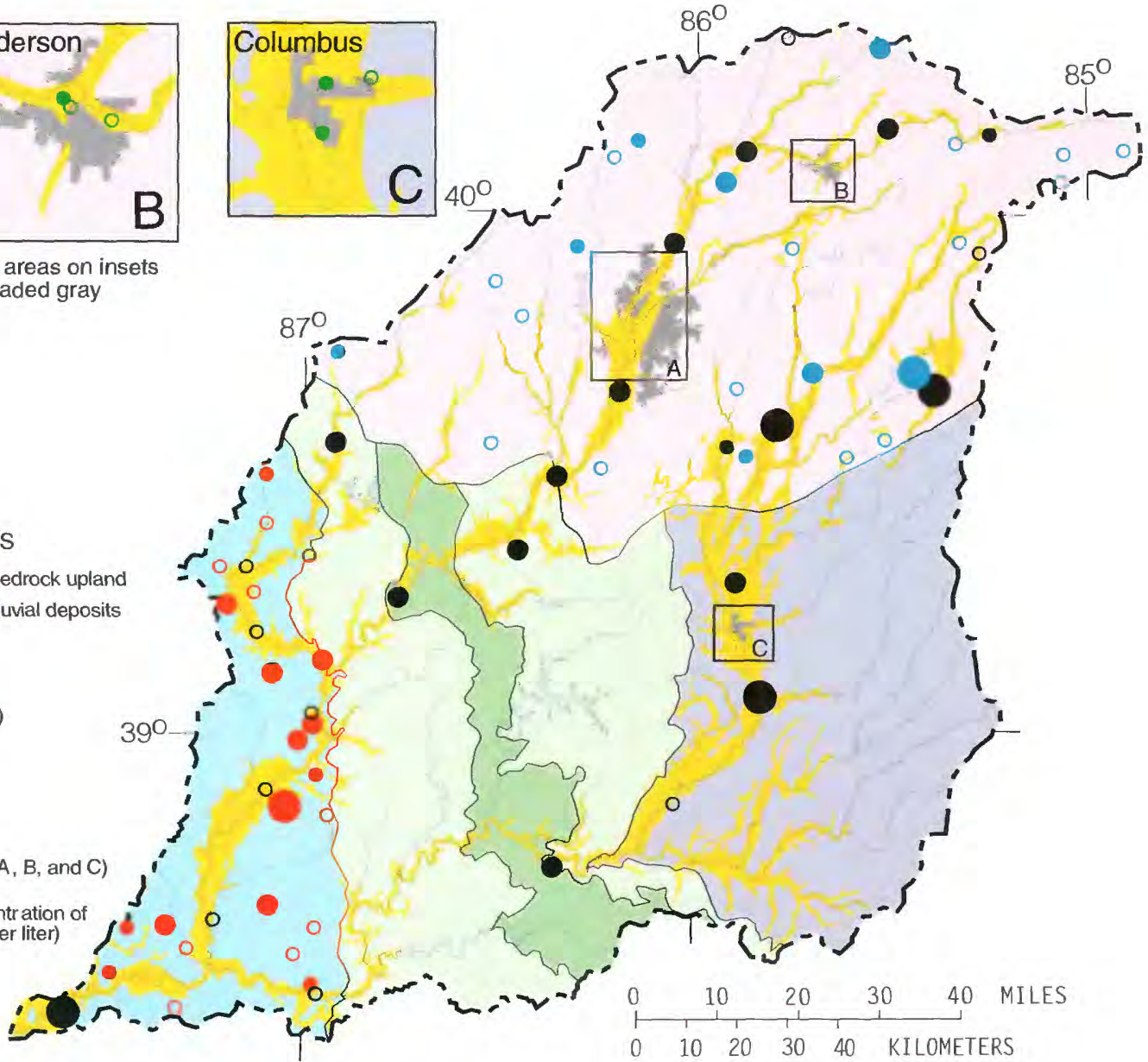

0
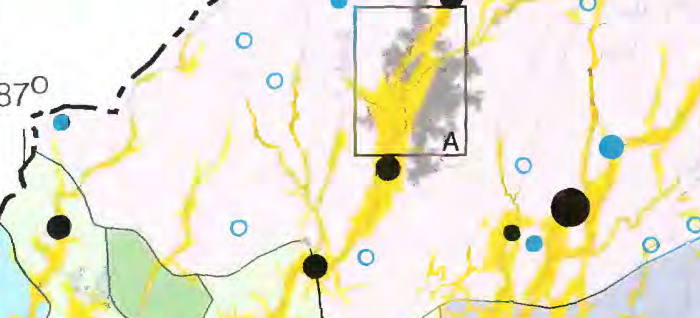

1
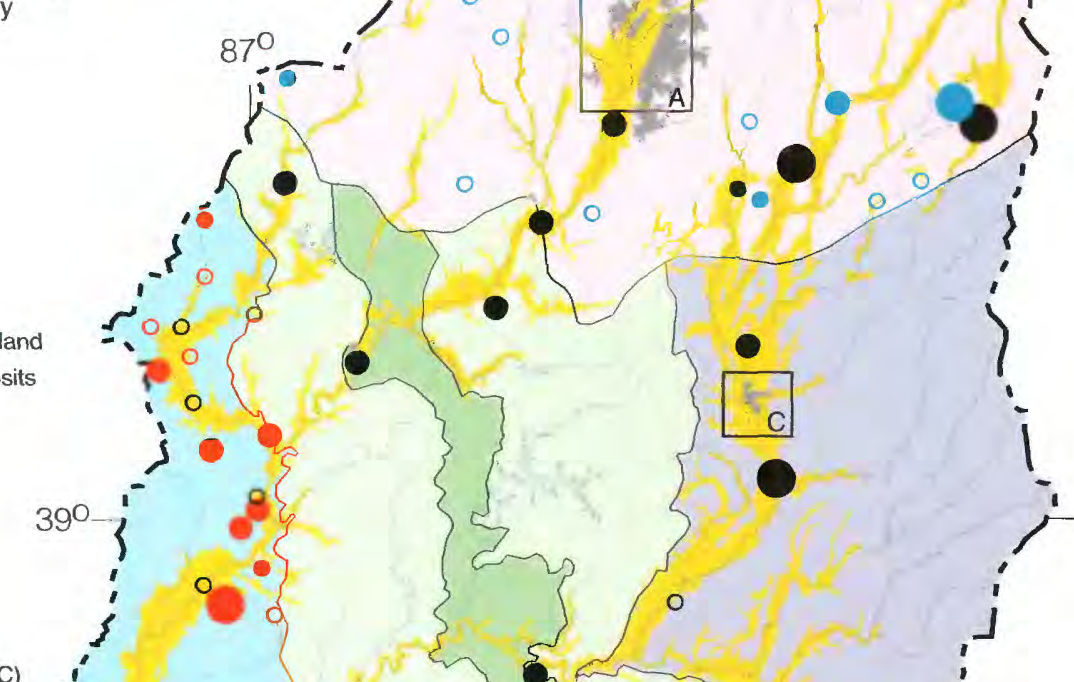
materials; (4) depth to water; (5) depth to aquifer (for confined aquifers); and (6) availability of dissolved oxygen in the aquifer. Ground water is most vulnerable to nitrate contamination in coarsetextured, well-drained deposits where leaching rates are high and dissolved oxygen is present.

\section{STUDY APPROACH}

The USGS installed four monitoring-well networks in the White River Basin (fig. 3). The networks are designed to assess the concentrations and distributions of nitrate in shallow, recently recharged (generally less than 10 years old) ground water in four different environmental settings. The environmental settings are defined by a combination of hydrogeomorphic and land-use characteristics.

Monitoring-well networks were installed in agricultural settings in the till plain ( 23 wells), the glacial lowland ( 22 wells), and the fluvial deposits ( 24 wells). An additional network was installed in the fluvial deposits ( 25 wells) in the urban settings of Indianapolis, Anderson, and Columbus (insets on fig. 3). The 94 wells in these four networks are referred to as "shallow wells" in this fact sheet. Nine additional "deep wells" were drilled in the two networks in fluvial deposits to compare nitrate concentration by depth. Six of the nine deep wells are in the fluvial/agricultural network, and the remaining three are in the fluvial/urban network. The deep wells were drilled adjacent to and 18 to 45 feet deeper than a paired shallow well and screened in the same unit as the shallow well. The depth of each deep well was determined by the depth to the bottom of the uppermost water-bearing unit or by the limit of the drill rig (50 to 70 feet).

Well locations within each network were randomly selected. A hollow-stem, rotary auger was used to install the 12- to 67-foot wells. Two-inch diameter polyvinyl chloride (PVC) wells with short screens ( 2.5 to 7.5 feet) were finished in the uppermost waterbearing unit using procedures described in Lapham and others (1995). Median well yields in the networks of the till plain and glacial lowland were low- -0.3 and less than 0.1 gallon per minute, respectively. Wells in the fluvial networks had median well yields of greater than 5 gallons per minute.

Procedures described in Koterba and others (1995) were used to collect filtered samples from the 103 monitoring wells in the summers of 1994 and 1995. The USGS National Water Quality Laboratory measured nitrate plus nitrite and nitrite concentrations using analytical methods described in Fishman and Friedman (1989). Nitrate concentrations were calculated by subtracting nitrite concentrations from nitrate plus nitrite concentrations. All nitrate concentrations are expressed as elemental nitrogen in this fact sheet. A quality-assurance program was used in the field and the laboratory to evaluate and ensure the reliability of the analytical data.

\section{FINDINGS}

Nitrate concentrations in water samples from the 94 shallow wells in the White River Basin ranged from less than $0.05 \mathrm{mg} / \mathrm{L}$ to a high of $21 \mathrm{mg} / \mathrm{L}$. High concentrations of nitrate in drinking water can have potentially hazardous effects on humans and livestock (National Research Council, 1978). Infants less than 6 months old are susceptible to methemoglobinemia (blue-baby syndrome), a condition in which ingested nitrate converts to nitrite and interferes with the blood's ability to carry oxygen. The U.S. Environmental Protection Agency has established a Maximum Contaminant Level of $10 \mathrm{mg} / \mathrm{L}$ for nitrate in drinking water, primarily to protect infants from methemoglobinemia (U.S. Environmental Protection Agency, 1995). Water from 6 of the 94 shallow wells (6.4 percent) contained nitrate concentrations higher than $10 \mathrm{mg} / \mathrm{L}$ (fig. 3). Although the monitoring wells installed for this study are not used for drinking water, the shallow ground water is sometimes used as a drinking-water supply, especially in the fluvial deposits region.

Nitrate was not detected, at a detection limit of $0.05 \mathrm{mg} / \mathrm{L}$, in 43 percent of the shallow wells. The detection limit is well below the concentration of nitrate in precipitation in the White River Basin - the source of water for the shallow aquifers. Precipitationweighted mean nitrate concentrations in the basin in 1993 were approximately $0.3 \mathrm{mg} / \mathrm{L}$ (National Atmospheric Deposition Program, 1994). In contrast to the wells with no detectable nitrate, samples from 29 percent of the shallow wells had nitrate concentrations higher than $3.0 \mathrm{mg} / \mathrm{L}$. In a national study of nitrate data from more than 120,000 wells, Madison and Brunett (1984) considered a nitrate concentration greater than $3.0 \mathrm{mg} / \mathrm{L}$ to indicate probable human influence. A nitrate concentration in ground water of $3.0 \mathrm{mg} / \mathrm{L}$ has been elevated approximately 10 times above the concentration of precipitation that falls in the basin.

The paired wells in the fluvial deposits show stratification of nitrate concentration with depth (fig. 4). The concentration of nitrate in samples from six of the shallow wells was higher than the concentration in the corresponding deep well. In the remaining three well pairs, no nitrate was detected in samples from either well. Nitrate concentrations are typically higher at the top of the water table than at depth, in part because most nitrate sources originate at the land surface (Hallberg and Keeney, 1993). Nitrate concentrations tend to decrease with depth as recharge water containing nitrate moves downward and mixes with water that is lower in nitrate. Stratification of nitrate concentrations with depth also is influenced by the availability of dissolved oxygen. As dissolved oxygen concentrations decrease with depth, loss of nitrate by denitrification is enhanced (Hallberg and Keeney, 1993). In five of the six paired wells displaying nitrate stratification, dissolved oxygen concentrations were higher in the shallow well than in the deep well.

The largest percentage of shallow wells with a nitrate concentration between 3.1 and $10 \mathrm{mg} / \mathrm{L}$ (42 percent) and the largest percentage of shallow wells with a nitrate concentration higher than $10 \mathrm{mg} / \mathrm{L}$ (17 percent) were in fluvial deposits underlying agricul-

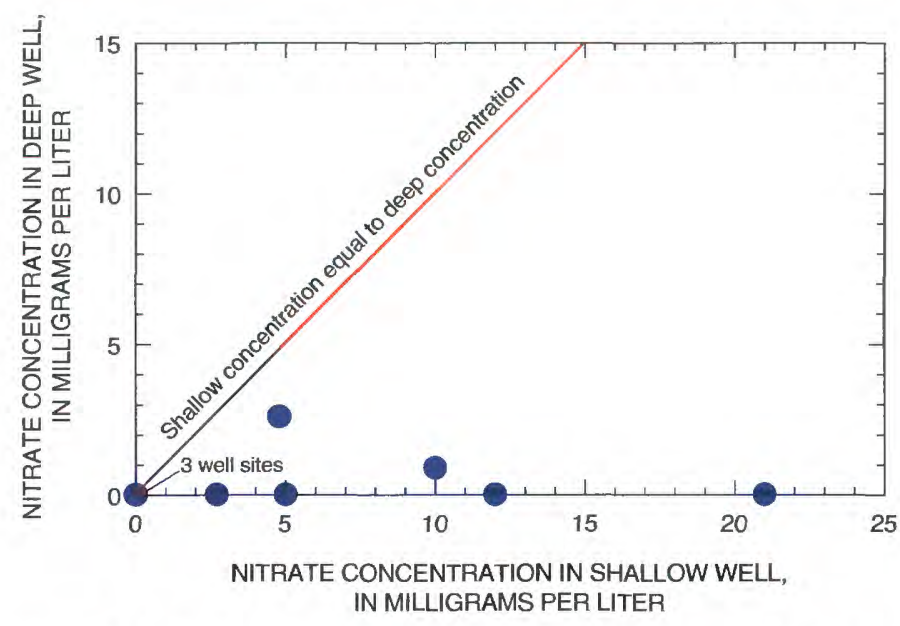

Figure 4. Nitrate concentrations in samples from paired shallow and deep wells in the fluvial deposits of the White River Basin, Indiana. 


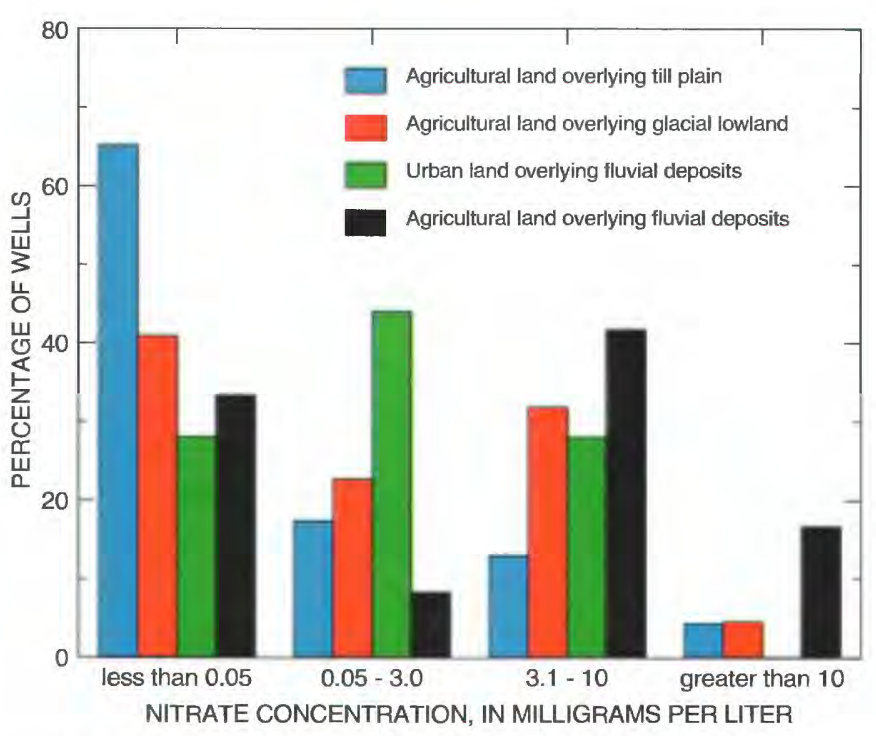

Figure 5. Distribution of nitrate in wells from four environmental settings in the White River Basin, Indiana.

tural land (figs. 3, 5). Similarly, in a large Statewide survey of private wells, Barnett and others (1994) found the highest concentrations of nitrate in wells less than 50 feet deep, proximal to cropland, and in sandy, permeable deposits.

Elevated nitrate concentrations are expected in water from the fluvial deposits underlying agricultural land; the primary source of nitrate for this water is nitrogen fertilizers applied to the land. The fluvial deposits are vulnerable to nitrate contamination because water infiltrates through them rapidly (Soller and Berg, 1992). Rapid infiltration allows nitrate to easily move below the root zone where it is not available for uptake by plants. In addition, rapid infiltration replenishes ground water with oxygen-rich recharge water, inhibiting nitrate loss by denitrification.

Nitrate concentrations in samples from three-fourths of the shallow wells in fluvial deposits underlying urban land were above the detection limit; however the nitrate concentration did not exceed $10 \mathrm{mg} / \mathrm{L}$ in any of the samples (fig. 5). This widespread, low-level contamination probably is due to (1) the vulnerable nature of the fluvial deposits, as explained above, and (2) the prevalent use of lawn fertilizers in urban settings. Effluent from septic systems and leaky sewers also may contribute lesser amounts of nitrate to the ground water in urban settings.

Water samples from more than one third of the wells in the glacial lowland had nitrate concentrations higher than $3.0 \mathrm{mg} / \mathrm{L}$.

Most of these wells were screened in dune sands that are not protected by an overlying clay-rich unit or were screened close to land surface (within 23 feet). Samples from only one well in the till plain and from one well in the glacial lowland exceeded a nitrate concentration of $10 \mathrm{mg} / \mathrm{L}$; in each case, the well was in an area with highly permeable, well-drained deposits.

Nitrate concentrations were below the detection limit in samples from approximately 65 percent of the wells in the till plain and 41 percent of the wells in the glacial lowland (fig. 5). Low concentrations of nitrate in ground water underlying agricultural areas of the till plain and the glacial lowland are common where overlying clay-rich tills retard downward movement of nitrate and oxygen into the water-bearing units. Low concentrations of dissolved-oxygen in the ground water of the till plain and glacial lowland settings enable nitrate to be denitrified, thus lowering nitrate concentrations.

\section{REFERENCES CITED}

Barnett, J.D.; Wallrabenstein, L.K.; Richards, R.P.; and Baker, D.B, 1994, Nitrate and pesticides in private wells of Indiana: Indiana Farm Bureau Inc., 38 p.

Fishman, M.J., and Friedman, L.C., eds., 1989, Methods for determination of inorganic substances in water and fluvial sediments: U.S. Geological Survey Techniques of Water-Resources Investigations, book 5, chap. A1, 545 p.

Hallberg, G.R., and Keeney, D.R., 1993, Nitrate, in Alley, W.M., ed., Regional ground-water quality: New York, N.Y., Van Nostrand Reinhold, p. 297-322.

Hirsch, R.M., Alley, W.M., and Wilber, W.G., 1988, Concepts for a national water-quality assessment program: U.S. Geological Survey Circular 1021, 42 p.

Koterba, M.T., Wilde, F.D., and Lapham, W.W., 1995, Ground-water data-collection protocols and procedures for the National WaterQuality Assessment Program-Collection and documentation of water-quality samples and related data: U.S. Geological Survey Open-File Report 95-399, 113 p.

Lapham, W.W., Wilde, F.D., and Koterba, M.T.,1995, Ground-water data-collection protocols and procedures for the National WaterQuality Assessment Program-Selection, installation, and documentation of wells, and collection of related data: U.S. Geological Survey Open-File Report 95-398, 69 p.

Madison, R.J., and Brunett, J.O., 1984, Overview of the occurrence of nitrate in ground water of the United States, in National water summary 1984: U.S. Geological Survey Water-Supply Paper 2275, p. 93-105.

National Research Council, 1978, Nitrates-An environmental assessment: Washington, D.C., National Academy Press, 723 p.

National Atmospheric Deposition Program, 1994, NADP/NTN annual data summary-Precipitation chemistry in the United States, 1993: Fort Collins, Colo., Natural Resource Ecology Laboratory. Colorado State University, $465 \mathrm{p}$.

Soller, D.R., and Berg, R.C., 1992, Using regional geologic information to assess relative aquifer contamination potential-An example from the central United States: U.S. Geological Survey Open-File Report 92-694, 1 plate.

U.S. Environmental Protection Agency, 1995, Drinking water regulations and health advisories: Washington, D.C., U.S. Environmental Protection Agency, Office of Water, $11 \mathrm{p}$.

U.S. Geological Survey Fact Sheet 110-96

Prepared by

Rhett C. Moore and Joseph M. Fenelon

For more information, contact:

Project Chief

White River Basin Study

U.S. Geological Survey

5957 Lakeside Blvd.

Indianapolis, Indiana 46278-1996

317-290-3333 